\title{
HUBUNGAN ANTARA KEKUATAN OTOT LENGAN DAN PANJANG LENGAN TERHADAP KEMAMPUAN OVERHAND PASS PADA ANGGOTA EKSTRAKULIKULER BOLA TANGAN SMK NEGERI 26 JAKARTA
}

\author{
Angga Rachmat Pribadi \\ Tirto Apriyanto dan Sujarwo
}

\begin{abstract}
ABSTRAK. Penelitian ini bertujuan untuk memperoleh informasi tentang Hubungan Antara Kekuatan Otot Lengan dan Panjang Lengan Terhadap Kemampuan Overhand pass pada anggota ekstrakulikuler Bola Tangan SMK Negeri 26 Jakarta.

Pengambilan data dilakukan di lapangan bola tangan SMK Negeri 26 Jakarta pada tanggal 18 September 2014 sampai dengan tanggal 18 Desember 2014. Penelitian ini menggunakan metode deskriptif dengan teknik studi korelasi,sampel yang digunakan yaitu anggota ekstrakulikulerBola Tangan SMK Negeri 26 Jakarta sebanyak 20 orang, pengambilan sampel dengan menggunakan teknik total sampling (jenuh atau padat).Teknik pengujian hipotesis dilakukan dengan menggunakan teknik analisis statistika korelasi sederhana dan korelasi ganda yang dilanjutkan dengan uji-t pada taraf signifikasi $\square=0,05$.

Hasil penelitian menunjukkan: pertama, terdapat hubungan yang berarti antara Kekuatan Otot Lengan dengan Overhand pass, dengan persamaan garis linier $\hat{Y}=20,44+0,59$ X1, koefisien korelasi (ry1) $=0,59$ dan koefisien determinasi $\left(\right.$ ry $\left.1^{2}\right)=0,3481$, yang berarti variabel Kekuatan Otot Lengan memberikan sumbangan dengan Overhand pass sebesar $34.81 \%$. Kedua, terdapat hubungan yang berarti antara Panjang Lengandengan Overhand pass, dengan persamaan garis linier $\hat{Y}=11,77+0,76 \mathrm{X} 2$, koefisien korelasi (ry2) $=0,76$ dan koefisien determinasi (ry2 ${ }^{2}$ ) $=0,5776$, yang berarti variabel Panjang Lengan hanya memberikan sumbangan dengan Overhand pass sebesar 57,76\%. Ketiga, terdapat hubungan yang berarti Antara Kekuatan Otot Lengan dan Panjang Lengan Dengan Overhand pass dengan persamaan garis linier $\hat{Y}=1,5+0,34 \mathrm{X} 1+0,63 \mathrm{X} 2$ , koefisien korelasi Ry1-2 $=0,83$ dan koefisien determinasi $(\text { Ry1-2 })^{2}=0,6889$ yang berarti variabel Kekuatan Otot Lengan dan Panjang Lengan memberikan sumbangan dengan Overhand passs sebesar $68,89 \%$.
\end{abstract}

\section{Kata Kunci : Bola Tangan, Overhand pass, Kekuatan Otot Lengan}

\section{PENDAHULUAN}

Permainan bola tangan merupakan salah satu permainan olahraga sama seperti halnya olahraga permainan sepak bola, bola basket, dan yang lainya. Karena permainan ini mengandalkan power (gabungan antara kekuatan dan kecepatan).

Secara esensi bola tangan adalah sebuah cabang olahraga permainan beregu yang menggunakan bola sebagai alatnya yang dimainkan dengan menggunakan satu atau kedua tangan dengan cara dilempar, dipantulkan, ditangkap atau ditembakkan.

Sedangkan secara aturan, bola tangan adalah sebuah cabang olahraga permainan yang menggunakan bola sebagai alatnya dengan tujuan memasukan bola ke gawang lawan sebanyak-banyaknya dan mencegah agar tim lawan tidak dapat memasukan bola ke gawang sendiri.

Bola tangan merupakan olahraga permainan yang merupakan kombinasi antara cabang olahraga bola basket dan sepak bola. Dimana teknik dasar permainan bola tangan adalah memantulkan dan mengoper bola dengan menggunakan tangan sama seperti permainan bola basket. Sedangkan dari segi peraturan bola tangan hampir sama dengan olahraga sepak bola dari lapangan dan menggunakan gawang sama seperti permainan sepak bola.

Di Indonesia permainan bola tangan telah dilakukan sejak jaman penjajahan Belanda, tetapi sayang sampai sekarang tidak banyak diketahui oleh masyarakat. Hal ini ternyata dengan tidak adanya top organisasi bola tangan, perkumpulan bola 
tangan begitu pula pertandingannya. Tetapi permulaan bola tangan telah dimasukkan dalam acara pertandingan PON ke - 11 Jakarta tahun 1951 yang diikuti oleh kontigen dari Jakarta, Jawa Barat, Jawa Tengah dan Jawa Timur jadi permainan bola tangan di Indonesia banyak dikenal oleh pelajar sekolah lanjutan sebagai salah satu pelajaran olahraga serta di kalangan angkatan bersenjata.

Bola tangan sekarang ini sedikit demi sedikit mulai berkembang di Indonesia. Hal tersebut terlihat dengan adanya organisasi yang membawahi cabang olahraga bola tangan ini, yaitu Asosiasi Bola tangan Indonesia (A.B.T.I). Dan selanjutnya diikuti oleh pendirian Klub Bola tangan FIK $-\mathrm{UNJ}$.

Olahraga ini kembali pertama kali dipertandingkan secara resmi di Indonesia pada kejuaraan bola tangan pasir yang merupakan salah satu cabang dalam Asian Beach Games 1 di Bali pada tahun 2008. Kemudian berkembang dengan adanya Kejuaraan Mahasiswa Bola tangan Indoor yang diselenggarakan di Universitas Negeri Jakarta pada tahun 2009. Seiring dengan berjalannya waktu, olahraga bola tangan pun semakin dikenal dikalangan pelajar dan mahasiswa. Oleh karena itu banyaknya terlaksana kejuaraan-kejuaraan nasional antar pelajar dan kejuaraan-kejuaraan Nasional antar perguruan tinggi setiap tahunnya. Bukan hanya itu, dengan semakin dikenalnya olahraga bola tangan, akhirnya provinsi Jawa Barat pun setiap tahunnya mengadakan kejuaraan se-Jawa Barat atau yang dikenal dengan nama "KEJURBAR".

Pada tahun 2010 kembali Indonesia mengikuti kejuaraan Olahraga pantai seAsia (ABG- Asian Beach Games) yang ke2, kejuaraan Olahraga pantai se-Asia ini diselenggarakan di MUSCAT-OMAN. Berakhirnya Asian Beach Games ke-2 ini membuat bola tangan semakin dikenal oleh kalangan pelajar dan mahasiswa, apa lagi dengan diadakannya kejuaraan Nasional Bola tangan indoor tingkat pelajar dan mahasiswa ke-3 yang diadakan oleh Universitas Negeri Jakarta Fakultas Ilmu Keolahragaan pada bulan Juli 2011. Dan klub bola tangan FIK -UNJ ikut bertanding dalam kejuaraan tersebut.
Berdasarkan pada kejuaraan mahasiswa dan pelajar Bola tangan Indoor yang sudah diselenggarakan, peneliti melihat anggota atau atlet klub bola tangan pelajar masih belum mampu memberikan kemampuan passing dengan baik, banyak diantara mereka masih lemah dalam melakukan passing, terutama passing jarak dekat maupun jarak jauh sehingga masih banyak kesalahan- kesalahan dasar dalam melakukan passing yang harus di tingkatkan.

Perlu diketahui pula bahwa bola tangan juga termasuk ke dalam salah satu cabang olahraga prestasi. Dalam olahraga prestasi terdapat beberapa komponen utama dalam peningkatan prestasi itu sendiri. Seperti yang dikatakan oleh Tudor O. Bompa dalam buku terjemahannya yang menyatakan bahwa faktor-faktor latihan yang perlu dipersiapkan dalam setiap program latihan pada setiap cabang olahraga adalah: persiapan fisik, persiapan teknik, persiapan taktik, dan persiapan kejiwaan yaitu mental. Bukan suatu hal yang instan dalam menjadikan sebuah cabang memiliki prestasi yang unggul. Oleh sebab itulah diperlukan adanya persiapan. Peneliti menemukan permasalahan dalam bola tangan terkait komponen fisik setiap atlet. Seperti yang dikatakan oleh Tudor O. Bompa bahwa persiapan fisik dan persiapan teknik merupakan dasar dalam membangun prestasi.

Bagian terlapak tangan sangat berpengaruh karena bagian telapak tangan harus berada di belakang bola sebab ini akan berpengaruh terhadap kerasnya hasil lemparan dan lebih penting memudahkan mengarahkan bola tepat kesasaran yang dituju.

Selain itu menurut mahendra menyatakan bahwa salah satu pola gerak dasar dominan dalam bola tangan adalah lempar dan tangkap yang merupakan keterampilan manipulatip. Dalam olahraga permainan bola tangan melempar merupakan keterampilan dasar yang harus ada pada olahraga ini, karena berfungsi sebagai usaha untuk melakukan operan (passing) atau lemparan ke gawang musuh. Semakin baik dalam lemparan bola maka dapat memudahkan seorang pemain 
melakukan operan (passing) maka dari pernyataan di atas diketahui bahwa operan (passing) dalam cabang olahraga bola tangan membutuhkan kecepatan dan juga kekuatan pada otot lengan.

\section{BOLA TANGAN}

Permainan bola tangan yang dimainkan pada masa Yunani kuno merupakan sebuah isyarat terciptanya olahraga bola tangan modern. Dimana bentuk permainan dan peraturannya masih sangat berbeda. Permainan "urania" yang dimainkan oleh orang-orang Yunani kuno dan Harpaston yang dimainkan oleh orangorang Romawi. Sebagaimana dalam "Fangballspiel" atau permainan "tangkap bola" yang diperkenalkan dalam sebuah lagu oleh seorang penulis puisi Jerman bernama Walther Von der Vogelwiede, di Perancis seorang bernama Rabeilas (1494-1533) menggambarkan permainan bola tangan dengan bermain menggunakan telapak tangan mereka. Pada tahun 1793 masyarakat Inuit yang hidup di dataran hijau menggambarkan dan membuat ilustrasi dengan menggunakan bolatangan. Pada tahun 1484 seorang administrator olahraga Denmark mengijinkan.

Permainan bolatangan agar dimainkan di sekolah lanjutan di Ortup Denmark dan mendorong untuk segera menyertakan aturan dalam bolatangan.

Permainan bola tangan yang kita kenal pada saat ini, pertama kali diperkenalkan pada tahun 1890 oleh seorang tokoh gymnastic dari jerman yaitu Konrad Koch. Akan tetapi permainan bola tangan ini tidak dapat langsung populer pada saat itu, karena bebagai alasan. Setelah perang dunia ke 1 selesai, dua orang Jerman yang lain itu Hirschman dan Dr. Schelenz, berusaha mempopulerkan kembali permainan bola tangan ini. Tahun 1928, bertepatan dengan dilangsungkanya Olimpic Games, wakil dari 11 negara mengadakan pertemuan di Amsterdam.

Dalam hasil pertemuan itu, terbentuklah suatu organisasi federasi bola tangan yang resmi yang disebut: Internasional Amateur Handball Federation (I.A.H.F) yang beranggotakan 11 negara. Presiden I.A.H.F pertama adalah Avery
Brundage, seorang anggota yang kemudian mejadi presiden dari Internasional Olympic Committe (I.O.C).

Akhirnya pada tahun 1946 atas ulasan dan undangan Denmark dan Swedia, 8 negara mendeklarasikan federasi bola tangan internasional atau International Handball Federation (IHF). Delapan negara tersebut adalah Denmark, Finlandia, Perancis, Belanda, Norwegia, Polandia, Swiss, Swedia. Sampai tahun 2003 IHF memiliki peserta sebanyak 150 negara dengan 80.000 klub dan 19 juta atlet putra dan putri. Pada tahun 2007, Indonesia secara resmi menjadi anggota IHF dengan nama Asosiasi Bola Tangan Indonesia (ABTI).

\section{KEKUATAN OTOT LENGAN}

Inti dari kekuatan otot lengan adalah untuk menghasilkan ketegangan terhadap suatu tahanan atau beban, sehingga orang akan lebih cepat mendorong, melempar lebih jauh dan efisien. Kekuatan otot memiliki pengertian sebagai kemampuan untuk melakukan kontraksi terhadap beban secara maksimal. Pate Rotella/Harsono mendefinisikan sebagai berikut:

Kekuatan maksimum yang dapat dipergunakan dengan satu kontraksi maksimal, ketahanan mengacu kepada kontraksi maksimal yang ditampilkan selama periode tertentu, kekuatan mencerminkan kemampuan seseorang menghasilkan kekuatan dan menampilkan gerak secara cepat. Dengan demikian kekuatan sangat penting dalam meningkatkan kondisi fisik secara keseluruhan. Sebagaimana oleh harsono menerangkan bahwa kekuatan otot adalah kekuatan yang sangat penting dalam meningkatkan kondisi fisik secara keseluruhan.

Lebih lanjut dijelaskan bahwa:

Pertama karena kekuatan merupakan daya penggerak setiap aktivitas fisik, kedua karena kekuatan memegang peranan yang penting dalam melindungi otot orang dari kemungkinan cidera, oleh karena dengan itu kekuatan, atlet dapat lebih melempar atau menendang lebih jauh, efisien, memukul atau melempar lebih keras, demikian pula dapat membantu memperkuat stabilitas sendi. 
Menurut Agus Mahendra power adalah suatu atribut fisik yang paling dominan yang diperlukan dalam bola tangan. Kebanyakan keterampilan bola tangan bergantung pada kualitas fisik yang satu ini dalam hal bahwa pebolatangan harus mengerakan tubuhnya atau bagian tubuhnya secara cepat, sehingga memerlukan kekuatan dan kecepatan secara stimulan.

Latihan dengan tahanan akan mempengaruhi hasil kerja otot baik secara anatomis dan fungsional. Secara fungsional akan mempengaruhi jumlah kerja yang akan dilakukan, sedangkan secara anatomis akan mempengaruhi susunan otot atau penambahan otot (hypertrophy). Penambahan otot tersebut dipengaruhi oleh kemampuan lengan untuk melempar bola. Kemampuan lengan tersebut merupakan sebuah tuas, dimana tuas tersebut berfungsi untuk memperingan kerja yang dilakukan oleh lengan. Tuas ini bertujuan untuk meningkatkan kekuatan otot lengan pada saat melempar. Makin besar kekuatan otot lengan pada saat melempar maka akan semakin jauh jarak bola yang dilemparkan. Gerakan dari otot lengan dalam melempar bola terjadi karena adanya koordinasi dari otot-otot lengan atas dan bawah yang diantaranya terdapat sendi siku.

Otot bisep membengkokkan lengan pada siku dan ditenteng oleh trisep dengan meluruskan tangan. Suatu gerakan jarang dihasilkan sebagai produk kontraksinya satu otot. Dalam gerakan badan dan anggota badan, beberapa grup terlibat dalam membuat satu gerakan. Sumbangan tiap otot dalam grup akan sangat bervariasi sesuai besarnya tenaga dan gerak yang diperlukan.

Bila pemain ingin mengerakan otot terlebih dahulu harus dengan mengkontraksinya. Serabut otot didalam otot berkontraksi dalam rangka menggunakan suatu kekuatan. Semakin besar tenaga/kekuatan yang ingin dihasilkan, semakin banyak serabut otot yang digunakan. Untuk mendapatkan hasil lemparan kedalam jarak jauh yang diinginkan, maka semakin banyak otot lengan yang terlibat. Otot lengan atas terdiri dari coraco branchialis, deltoids, biceps, biceps brachi, triceps brachi. Otot lengan bawah terdiri dari otot-otot brachioradialis, suprinator pronator teres, extensor digitorum, flexor digitorum, sperticialis, flexor profundus.

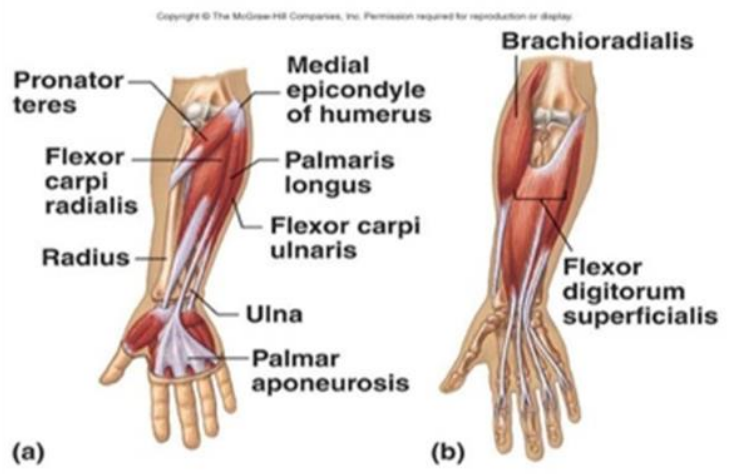

Gambar 1 : Otot Lengan Bawah Sumber :

http://kingberaksi.blogspot.com/2013/03/be berapa-otot-otot-manusia.html

Diakses pada tanggal 20 Januari 2014, pukul 11.30

Otot-otot tersebut bekerja dalam
keadaan flexsi diakibatkan otot-otot ventralis atau disebut juga otot-otot lengan atas (brachialis) yang berhubungan dengan claricle dan skapula dalam keadaan kontraksi konsentris. Disebut kontraksi konsentris bila terbentuk tegangan dalam otot dan terlihat otot tersebut megerut. Sedangkan otot bagian bawah yang berhubungan dengan otot bagian bawah dalam keadaan kontraksi statis. Kontraksi statis terjadi bilamana tebentuk tegangan dalam otot tetapi tanpa terlihat adanya pengerutan atau pemanjangan dari otot.

Olahraga permainan pada masa sekarang ini lebih cenderung mengarah pada komponen biomotor daya ledak (power). Karena olahraga permainan yang lainya cenderung memiliki kekuatan dan kecepatan.

Seperti yang dikatakan harsono dalam bukunya yaitu power lebih diperlukan dan boleh dikatakan semua cabang olahraga. Oleh karena power, kecuali ada kekuatan terdapat pula kecepatan. Sama halnya dengan kedua cabang olahraga tersebut. 
Cabang oalahraga bola tangan juga mengandalkan kekuatan.

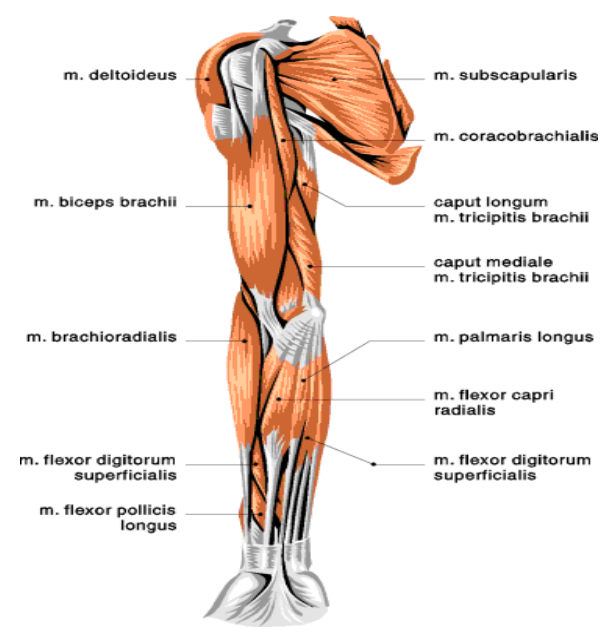

Gambar 2 : Otot Lengan

Sumber : http://www.siskatheanalyst.blogspot.com/2012/03/miologi.ht $\mathrm{ml}$

Diakses pada tanggal 20 Januari 2014, pukul 11.30

Penentu-penentu tenaga ledak otot (muscular power) adalah :

a. Kekuatan Otot

b. Kecepatan rangsang saraf serta kecepatan kontraksi otot.

Kekuatan otot sangat diperlukan di dalam permainan bola tangan, dengan otot yang telah dilatih secara berkala, maka akan didapatkan suatu kekuatan yang dapat menghasilkan tenaga yang besar untuk melakukan sesuatu teknik di dalam permainan bola tangan, khususnya dalam melakukan passing kepada teman dalam tim. Sangat diperlukan Karena permainan bola tangan merupakan permainan yang dimainkan secara cepat. Dalam melakukan teknik terutama teknik passing diperlukan kecepatan rangsang saraf dan kontraksi otot. Dan jika kekuatan dan kecepatan tersebut digabung akan menghasilkan passing yang cepat dan akurat.

Jadi dengan memiliki otot lengan yang kuat maka seorang atlet khususnya atlet bola tangan akan dapat menciptakan hasil passing bola ke teman satu tim dengan cepat dan terarah.

\section{PANJANG LENGAN}

Postur tubuh merupakan salah satu faktor yang mempengaruhi pencapaian prestasi optimal atlet dilihat dari aspek bola tangan, disamping faktor-faktor lainya seperti kondisi fisik, mental dan keterampilan atau teknik satu dengan yang lainya saling terkait, saling mempengaruhi serta tidak dapat dipisahkan, semua faktor tersebut menjadi satu dalam latihan.

Dalam permainan bola tangan, lengan merupakan anggota tubuh yang mempunyai peranan yang paling besar didalam melakukan lemparan, dorongan serta mendrible bola. Lengan yang panjang akan menghasilkan jenis lemparan yang jauh dan efisien. Hal ini disebabkan karena selain yang telah dibahas di atas (kekuatan otot lengan), lengan yang panjang akan menempuh suatu lintasan yang panjang dan jauh.

Bila dilihat dari kata panjang lengan, tentunya akan jelas terlihat bahwa kata tersebut terdiri dari (dua) kata, yaitu kata panjang dan lengan, dalam kamus bahasa Indonesia edisi kedua kata tersebut memiliki arti panjang berarti jarak jauh (dari ujung ke ujung). Selanjutnya dijelaskan pula dalam kamus bahasa Indonesia edisi kedua lengan memiliki pengertian. Anggota badan dari pergelangan tangan sampai ke bahu. Dari pengertian tersebut, lengan masih dibagi menjadi (dua) bagian yaitu lengan atas dan lengan bawah.

Lengan atas dimulai dari bagian atas bahu sampai batas terjadinya pergerakan fleksi. Lengan bawah dimulai dari batasan gerakan fleksi tersebut sampai dengan ujung pergelangan tangan. Kemudian panjang lengan tersebut dapat juga diartikan sebagai jarak antara tulang humerus dengan sikap lurus menuju tulang radius dan tulang ulna.

Jenis tulang tersebut merupakan bagian dari extermitas superior, tulang yang termasuk kebagian jenis tulang besar yaitu tulang lengan. Lebih lengkapnya adalah: humerus, radius, ulna, ossa karpalia, ossa metakarpalia, falanges. Lengan yang terdiri dari beberapa tulang tersebut masih diselimuti oleh otot-otot yang saling 
bersilangan satu sama lain. Otot-otot tersebut akan menempel pada tulangdan bergerak pada gerakan abduksi yaitu gerakan yang arahnya ke dalam anggota badan. Mochamad soebroto menjelaskan, bahwa semakin tinggi dan semakin besar orangnya maka semakin baik, lengan pun demikian semakin panjang dan makin baik. Orang yang memiliki bentuk lengan yang panjang didalam melakukan suatu kegiatan atau kerja, baik dalam melakukan suatu dorongan atau lemparan akan menghasilkan dorongan dan lemparan yang jauh dan efisien, karena pada saat melakukan dorongan atau lemparan terdapat jarak dorong atau lempar yang lebih panjang.

Seorang atlet bola tangan yang memiliki panjang lengan yang maksimal akan menghasilkan lemparan yang jauh dan efisien, dan atlet tersebut juga dapat dengan mudah mengarahkan passing bola ke teman satu tim ke posisi tersulit yang tidak dapat dicapai oleh lawan.

\section{OVERHAND PASS}

Pada cabang olahraga bola tangan teknik passing yang paling sering di gunakan adalah teknik Overhand pass karena operan ini relatif sangat mudah dilakukan dan selain itu juga dapat dilakukan dengan cepat dan terarah. Hal ini sangat penting karna pada saat bermain dalam usaha membangun serangan pemain harus bergerak dengan cepat, operan jarak pendek maupun jarak jauh yang terarah untuk mencegah bola terambil dari pemain bertahan.

Overhand pass adalah mengoper bola dengan satu tangan dari atas bahu dilihat dari jenisnya dapat di bedakan berdasarkan dua tujuan yaitu pertama untuk mengoper teman seregu yang berjarak dekat maupun jauh dan yang ke dua untuk mengecoh lawan khusus Overhand pass, pelaksanaan harus dilakukan dengan mengikuti prinsip maxsimum time-distance, dalam arti bahwa lemparan itu dilakukan dalam waktu yang maxsimum (secepatcepatnya) dan jarak sikap melempar power posision.

Passing dan menangkap adalah komponen yang paling penting. Ketidakmampuan untuk mengontrol bola hasil hilangnya kepemilikan dan meningkatkan peluang mencetak gol bagi lawan. Keberhasilan menyerang suatu tim. Kemampuan untuk memindahkan bola dengan cepat dan akurat dari satu pemain ke yang lain.

Tenaga yang diperlukan untuk mengoper bola di hasilkan dari gerakan tubuh yang bergerak kedepan, yang kemudian disalurkan dan digabungkan dengan tenaga lengan, tangan dan pergelangan tangan.

Rangkaian gerak Overhand pass:

1. Posisi badan harus menghadap kearah sasaran

2. Bola di pegang dengan satu tangan dimana jari-jari yang terbuka lebar di usahakan dapat menguasai bola sepenuhnya

3. Bagian telapak tangan harus berada tepat di belakang bola. sebab ini akan berpengaruh terhadap kerasnya hasil lemparan dan yang lebih penting adalah memudahkan mengarahkan bola tepat kesasaran yang dituju.

4. Bila telapak tangan tidak berada di belakang bola, setelah bola di lempar, jalan bola akan berputar hal ini akan menyulitkan teman dalam menangkap bola tersebut.

5. Tangan yang memegang bola di tarik ke arah belakang bahu diatas kepala.

6. Lengan yang tidak memegang bola di rentangkan ke depan setinggi bahu mengarahkan ke sasaran, dengan maksud menjaga keseimbangan.

7. Pelaksanaan lemparan di awali dengan ayunan lengan dan di akhiri dengan gerakan lecutan pergelangan tangan.

8. Sikap akhir dari Overhand pass adalah jari-jari tangan dari lengan yg melakukan lemparan menghadap ke arah sasaran. 


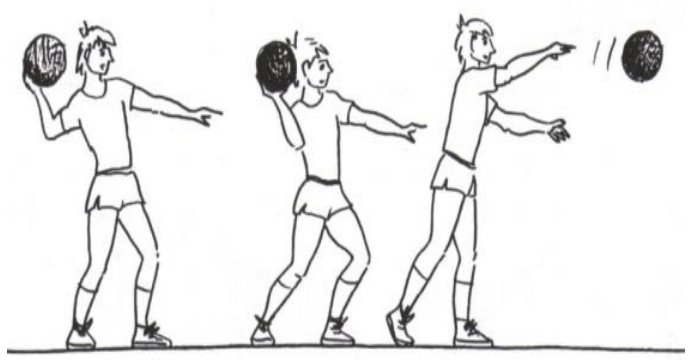

Gambar 3 : Rangkaian gerakan Overhand pass

Sumber:

http://www.Fellardiani.wordpress.com

Diakses pada tanggal 20 Januari 2014, pukul 11.30

Kekurangan Overhand pass

1. Jika posisi badan tidak mengarah ke sasaran maka akan sulit untuk melempar bola.

2. Bila telapak tangan tidak berada di belakang bola, setelah di lempar jalan bola akan berputar hal ini akan menyulitkan teman dalam menangkap bola tersebut.

Kelebihan Overhand pass

1. Lemparan Overhand pass sangat baik di gunakan untuk serangan balik dan operan pendek karna lemparan ini di lakukan dengan cepat dan terarah.

2. Untuk mengecoh lawan lemparan di lakukan dalam waktu yang maxsimum ( secepat-cepatnya).

\section{KERANGKA BERPIKIR}

\section{Hubungan Kekuatan Otot Lengan Dengan Overhand pass}

Pada cabang olahraga bola tangan, overhand pass merupakan salah satu teknik dasar yang merupakan syarat penting agar dapat bermain bola tangan dengan baik. Penguasaan teknik dasar merupakan syarat penting agar dapat bermain bola tangan dengan baik. Untuk menguasai teknik tersebut dibutuhkan keahlian yaitu dapat melakukan overhand pass dengan kekuatan, dalam hal ini kekuatan otot lengan. passing merupakan gerakan yang dilakukan otot lengan dengan gerakan abduksi yaitu gerak arah tangan ke depan badan untuk menghasilkan kuatnya passing. Gerakan terjadi karena adanya koordinasi dari otototot lengan atas dan otot-otot lengan bawah.

Otot lengan bagian atas dalam keadaan kontraksi atau terjadi ketegangan dalam otot dan terlihat otot tersebut mengkerut dan otot lengan bagian bawah dalam keadaan kontraksi statis atau terjadi ketegangan dalam otot tetapi tanpa terlihat adanya pengerutan atau perpanjangan dari otot.

Saat passing pada bagian lengan terjadi gerakan abduksi yaitu gerak arah tangan kanan ke belakang badan dan gerakan abduksi yaitu passing hasilnya akan baik pula. Semakin kuat dan cepat dalam melakukan passing dan semakin sulit pula lawan untuk mengantisipasinya. Jadi jelas bahwa mampu tidaknya pemain melakukan passing yang cepat dan terarah dipengaruhi oleh kekuatan dari otot lengan.

Dari uraian di atas dapat disimpulkan bahwa diduga ada hubungan yang berarti antara kekuatan otot lengan dengan overhand pass.

\section{Hubungan Panjang Lengan Dengan overhand pass}

Di dalam melakukan overhand pass dalam permainan bola tangan, selain faktor kekuatan otot lengan juga dipengaruhi oleh panjang lengan pemain. Karena dalam melakukan passing terdapat jarak dalam melakukan passing tangan pemain menempel pada bola sampai saat tangan melepaskan bola ke arah teman.

Seorang pemain bola tangan yang memiliki lengan panjang dalam melakukan passing akan menghasilkan operan yang lebih akurat dan susah diantisipasi oleh lawan. Sedangkan pemain yang mempunyai lengan yang pendek dalam melakukan passing dari tangan menempel pada bola sampai tangan melepaskan bola, akan menghasilkan gerak ayunan tangan yang pendek dan sedikit tambahan tenaga didalam melempar bola ke arah teman. Gerak ayunan dalam passing tersebut dilakuakan oleh 
lengan tangan dengan gerakan abduksi pada tangan kanan dan gerakan abduksi pada tangan kiri, arah dari gerak tersebut adalah ke kiri badan.

\section{Hubungan antara kekuatan Otot Lengan dan Panjang Lengan terhadap overhand pass.}

Passing merupakan rangkaian gerakan antara gerakan awalan, gerakan passing bola harus sampai lepas dari kedua tangan dan gerakan lanjutan. Didalam passing, kekuatan otot lengan merupakan penghasil tenaga dorong kemudian dilanjutkan ayunan tangan oleh lengan sampai ayunan lengan, lengan yang panjang akan menghasilkan gerak ayunan tangan yang panjang dan dorongan tenaga yang lebih banyak dalam melakukan passing yang tepat.

Dalam melaksanakan persiapan awalan melepar akan menentukan kekuatan maksimal dalam melakukan passing. Gerakan awalan, posisi badan, tangan siap untuk melakukan gerakan passing dan otot lengan persendian bahu dan lengan bawah fleksi terhadap persendian siku.

Gerakan passing disebabkan bekerjanya otot-otot lengan atas dan otototot lengan bawah dalam keadaan fleksi. Otot lengan atas bekerja dalam keadaan kontraksi konsentris dan otot lengan bawah bekerja dalam keadaan kontraksi statis. Jadi kekuatan otot lengan dan panjang lengan memberikan sumbangan yang positif pada passing. Maka kedua variabel bebas tersebut secara bersama-sama akan menunjukan hubungan yang berarti pula dengan overhand pass.

Melihat bahasan di atas maka diduga bahwa kekuatan otot lengan dan panjang lengan seseorang mempunyai hubungan yang berarti dengan kemampuan passing yang baik dalam permainan bola tangan.

\section{PENGAJUAN HIPOTESIS}

Berdasarkan kerangka berpikir :

1. Terdapat hubungan yang berarti antara kekuatan otot lengan dengan overhand pass.

2. Terdapat hubungan yang berarti antara panjang lengan dengan overhand pass.

3. Terdapat hubungan yang berarti antara kekuatan otot lengan dan panjang lengan secara bersama terhadap overhand pass.

\section{HASIL PENELITIAN}

Deskripsi data dimaksudkan untuk memperoleh gambaran tentang penyebaran data yang meliputi nilai terendah, nilai tertinggi, rata-rata, simpangan baku,distribusi frekuensi, varians, serta histogram dari masing-masing variabel X1, $\mathrm{X} 2$ dan $\mathrm{Y}$.

Berikut data lengkapnya :

Tabel 4. Deskripsi Data Penelitian

\begin{tabular}{|c|c|c|c|}
\hline Variabel & $\begin{array}{c}\text { Kekuatan } \\
\text { Ototlengan } \\
\left(X_{1}\right)\end{array}$ & $\begin{array}{c}\text { Panjang } \\
\text { Lengan } \\
\left(X_{2}\right)\end{array}$ & $\begin{array}{c}\text { OverHand Pass } \\
(Y)\end{array}$ \\
\hline Nilatierendah & 2.2 & 78 & 20 \\
\hline Nilaitertingai & 5.6 & 87 & 25 \\
\hline Rata-rata & 3.87 & 82.55 & 22.15 \\
\hline Simpanganbaku & 0.90 & 2.35 & 1.39 \\
\hline Varians & 0.81 & 5.52 & 1.92 \\
\hline
\end{tabular}

1. Variabel Kekuatan Otot Lengan (X1)

Hasil penelitian menunjukkan rentang skor kekuatan otot lengan (X1) adalah antara 2.2 sampai dengan 5.6, nilai rata-rata sebesar 3.87 simpangan baku sebesar 0.92. Distribusi frekuensi dapat dilihat pada tabel 2 di bawah ini: 
Tabel 5. Distribusi Frekuensi Kekuatan Otot Lengan (X1)

\begin{tabular}{|c|c|c|c|c|}
\hline \multirow{2}{*}{ No } & Interval & \multicolumn{3}{|c|}{ Frekuensi } \\
\cline { 3 - 5 } & Kelas & Nilai Tengah & Absolut & Relatif (\%) \\
\hline 1 & $2.1-2.78$ & 2,44 & 2 & $10 \%$ \\
\hline 2 & $2.88-3.56$ & 3,22 & 5 & $25 \%$ \\
\hline 3 & $3.66-4.34$ & 4 & 6 & $30 \%$ \\
\hline 4 & $4.44-5.12$ & 4,78 & 5 & $25 \%$ \\
\hline 5 & $5.22-5.90$ & 5,56 & 2 & $10 \%$ \\
\hline & Jumlah & & 20 & $100 \%$ \\
\hline
\end{tabular}

Berdasarkan tabel 5 di atas dibandingkan dengan nilai rata-rata, terlihat testee yang berada pada kelas rata-rata sebanyak 6 testee $(30 \%)$ dan yang berada di bawah kelas rata-rata sebanyak 7 testee (35\%), sedangkan testee yang berada di atas kelas rata-rata sebanyak 7 testee $(35 \%)$. Selanjutnya histogram variabel kekuatan otot lengan dapat dilihat pada gambar di bawah ini :

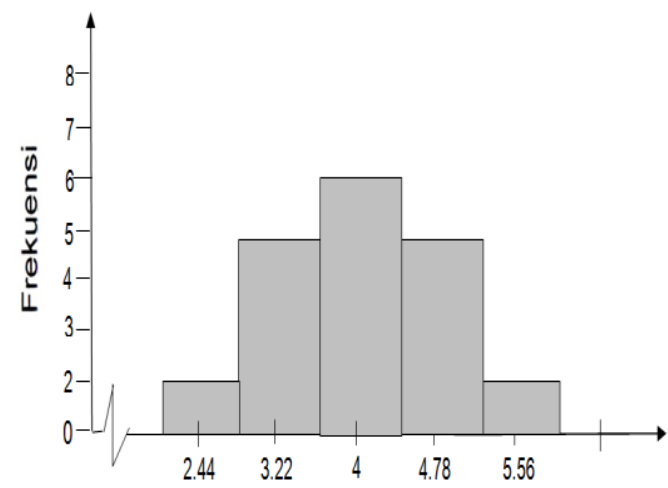

Gambar 7. Grafik Histogram DataKekuatan Otot lengan (X1)

\section{Variabel Panjang Lengan (X2)}

Hasil penelitian menunjukkan rentang skor panjang lengan (X2) adalah antara 78 sampai dengan 87 , nilai rata-rata sebesar 82.55 simpangan baku sebesar 2.35 Distribusi frekuensi dapat dilihat pada tabel 6 di bawah ini.
Tabel 6. Distribusi Frekuensi Panjang Lengan (X2)

\begin{tabular}{|c|c|c|c|c|}
\hline \multirow{2}{*}{ No } & Interval & \multicolumn{3}{|c|}{ Frekuensi } \\
\cline { 3 - 5 } & Kelas & Nilai Tengah & Absolut & Relatif (\%) \\
\hline 1 & $77-78.8$ & 77.9 & 2 & $10 \%$ \\
\hline 2 & $78.9-80.9$ & 79.9 & 4 & $20 \%$ \\
\hline 3 & $81.9-83.9$ & 82.9 & 9 & $45 \%$ \\
\hline 4 & $84.9-86.9$ & 85.9 & 4 & $20 \%$ \\
\hline 5 & $87.9-89.9$ & 88.9 & 1 & $5 \%$ \\
\hline & Jumlah & & 20 & $100 \%$ \\
\hline
\end{tabular}

Berdasarkan tabel 6 di atas dibandingkan dengan nilai rata-rata, terlihat testee yang berada pada kelas rata-rata sebanyak 9 testee $(45 \%)$ dan yang berada di bawah kelas rata-rata sebanyak 6 testee (30\%), sedangkan testee yang berada di atas kelas rata-rata sebanyak 6 testee $(30 \%)$. Selanjutnya histogram variabel panjang lengan dapat dilihat pada gambar di bawah ini :

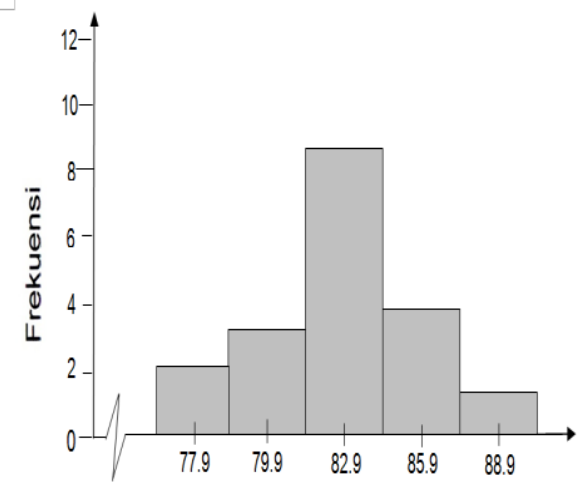

Gambar 8. Grafik Histogram Data Panjang Lengan (X2)

\section{Variabel Overhand pass (Y)}

Hasil penelitian menunjukkan rentang skor Overhand pass (Y) adalah antara 20 sampai dengan 25 , nilai rata-rata sebesar 22,15 simpangan baku sebesar 1.39. Distribusi frekuensi dapat dilihat pada tabel 4 di bawah ini : 
Tabel 7. Distribusi Frekuensi Overhand $\operatorname{pass}(\mathrm{Y})$

\begin{tabular}{|c|c|c|c|c|}
\hline \multirow{2}{*}{ No } & \multirow{2}{*}{$\begin{array}{l}\text { Interval } \\
\text { Kelas }\end{array}$} & \multicolumn{3}{|c|}{ Frekuensi } \\
\hline & & Nilai Tengah & Absolut & Relatif $(\%)$ \\
\hline 1 & $20-21$ & 20.5 & 6 & $30 \%$ \\
\hline 2 & $21.1-22.1$ & 21.6 & 6 & $30 \%$ \\
\hline 3 & $22.2-23.2$ & 22.7 & 5 & $25 \%$ \\
\hline 4 & $22.3-24.3$ & 23.8 & 2 & $10 \%$ \\
\hline 5 & $24.4-25.4$ & 24.9 & 1 & $5 \%$ \\
\hline & Jumlah & & 20 & $100 \%$ \\
\hline
\end{tabular}

dibandingkan dengan nilai rata-rata, terlihat testee yang berada pada kelas rata-rata sebanyak 5 testee $(25 \%)$ dan yang berada di bawah kelas rata-rata sebanyak 12 testee $(60 \%)$, sedangkan testee yang berada di atas kelas rata-rata sebanyak 3 testee $(15 \%)$. Selanjutnya histogram variabel Overhand pass dapat dilihat pada gambar di bawah ini

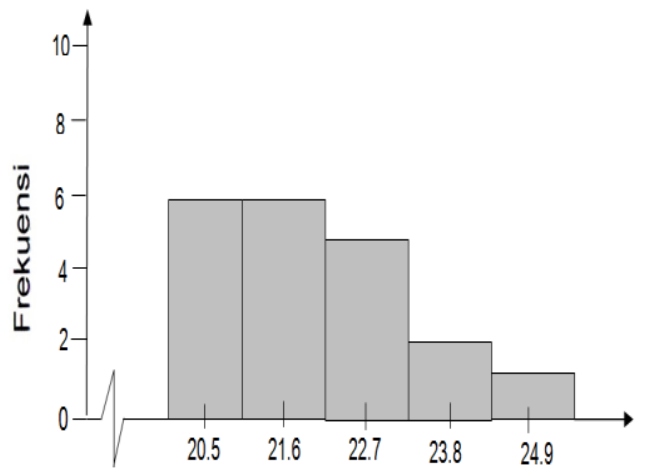

Gambar 9. Grafik Histogram Data Overhand Pass(X2)

\section{PENGUJIAN HIPOTESIS}

\section{Hubungan Antara Kekuatan Otot Lengan Dengan Overhand Pass}

Hubungan antara Kekuatan Otot Lengan dengan Overhand pass dinyatakan oleh persamaan regresi $\hat{Y}=20.44+0.59 \mathrm{X}_{1}$. Artinya hasil Overhand Pass dapat diketahui atau diperkirakan dengan persamaan regresi tersebut, jika variabel Kekuatan Otot Lengan $\left(\mathrm{X}_{1}\right)$ diketahui.
Hubungan antara Kekuatan Otot Lengan $\left(\mathrm{X}_{1}\right)$ dengan Overhand Pass (Y) ditunjukan oleh koefisien korelasi ry $1=$ 0,59 . Koefisien korelasi tersebut harus diuji terlebih dahulu mengenai keberartiannya, sebelum digunakan untuk mengambil kesimpulan. Hasil uji koefisien korelasi tersebut dapat dilihat dalam tabel berikut :

Tabel 8. Uji Keberartian Koefisien Korelasi $\left(\mathrm{X}_{1}\right)$ dengan $(\mathrm{Y})$

\begin{tabular}{|c|c|c|}
\hline $\begin{array}{c}\text { Koefisien } \\
\text { korelasi }\end{array}$ & t.hitung & t.tabel \\
\hline 0,59 & 3,11 & 2,101 \\
\hline
\end{tabular}

Dari uji keberartian koefisien korelasi di atas terlihat bahwat.hitung $=3,11$ lebih besar dari t,tabel $=2,101$ berarti koefisien korelasi ry1 $=0,59$ adalah signifikan. Dengan demikian hipotesis yang mengatakan terdapat hubungan yang berarti antara Kekuatan Otot Lengan dengan Overhand Pass di dukung oleh data penelitian, yang berarti semakin baik power otot lengan akan baik pula Overhand Pass. Koefisien determinasi Kekuatan otot lengan dengan Overhand pass $\left(\mathrm{ry}^{2}{ }^{2}\right)=0,3481$ hal ini berarti bahwa $34,81 \%$ Overhand pass ditentukan oleh Kekuatan otot lengan $\left(\mathrm{X}_{1}\right)$.

\section{Hubungan Antara Panjang Lengan Dengan Overhand Pass}

Hubungan antara Panjang Lengan dengan Overhand Pass dinyatakan oleh persamaan regresi $\hat{\mathrm{Y}}=11.77+0.76 \mathrm{X}_{2}$. Artinya hasil overhand pass dapat diketahui atau diperkirakan dengan persamaan regresi tersebut, jika variabel panjang lengan $\left(\mathrm{X}_{2}\right)$ diketahui.

Hubungan antara Panjang Lengan $\left(\mathrm{X}_{2}\right)$ dengan Overhand Pass $(\mathrm{Y})$ ditunjukan oleh koefisien korelasi ry2 $=0,76$. Koefisien korelasi tersebut harus diuji terlebih dahulu mengenai keberartiannya, sebelum digunakan untuk mengambil kesimpulan. Hasil uji koefisien korelasi tersebut dapat dilihat dalam tabel berikut : 
Tabel 9. Uji Keberartian Koefisien Korelasi $\left(\mathrm{X}_{2}\right)$ dengan $(\mathrm{Y})$

\begin{tabular}{|c|c|c|}
\hline $\begin{array}{c}\text { Koefisien } \\
\text { korelasi }\end{array}$ & t.hitung & t.tabel \\
\hline 0,76 & 5.03 & 2,101 \\
\hline
\end{tabular}

Dari uji keberartian koefisien korelasi di atas terlihat bahwa t.hitung $=5.03$ lebih besar dari t,tabel $=2.101$ berati koefisien korelasi ry1 $=0.76$ adalah signifikan. Dengan demikian hipotesis yang mengatakan terdapat hubungan yang berarti antara Panjang Lengan dengan Overhand Pass didukung oleh data penelitian.Koefisien determinasi Panjang Lengan dengan Overhand Pass $\left(\mathrm{ry}^{2}{ }^{2}\right)=$ 0.5776 hal ini berarti bahwa $57.76 \%$ Overhand Pass ditentukan oleh Panjang Lengan $\left(\mathrm{X}_{2}\right)$.

3. Hubungan Antara Kekuatan Otot lengan Dan Panjang Lengan Dengan Overhand Pass Pada Anggota Ekstrakurikuler Bola Tangan SMK Negeri 26 Jakarta

Hubungan antara Kekuatan Otot Lengan $\left(\mathrm{X}_{1}\right)$ dan Panjang Lengan $\left(\mathrm{X}_{2}\right)$ dengan Overhand Pass $(\mathrm{Y})$ dinyatakan oleh persamaan regresi $\hat{Y}=1.5+0.34 \mathrm{X}_{1}+0.63$ $\mathrm{X}_{2}$. Sedangkan hubungan antara ketiga variabel tersebut dinyatakan oleh koefisien korelasi ganda Ry1-2 =0,83. Koefisien korelasi ganda tersebut, harus di uji terlebih dahulu mengenai keberartiannya sebelum digunakan untuk mengambil kesimpulan. Hasil uji koefiesien korelasi ganda tersebut dapat dilihat dalam tabel berikut :

Tabel10.Uji Keberartian Koefisien Korelasi Ganda

\begin{tabular}{|c|c|c|}
\hline $\begin{array}{c}\text { Koefisien } \\
\text { korelasi }\end{array}$ & F.hitung & F.tabel \\
\hline 0,83 & 18.50 & 4.45 \\
\hline
\end{tabular}

Uji keberartian koefisien korelasi di atas terlihat bahwa F.hitung $=18.50$ lebih besar dari F.tabel $=4.45$. Berarti koefisien tersebut Ry1-2 = 0,83 adalah signifikan. Koefisien determinasi $\left(\mathrm{Ry}_{1.2}\right)^{2}=0,6889$ hal ini berarti bahwa $68.89 \%$ Overhand Pass ditentukan oleh Kekuatan Otot Lengan dan Panjang Lengan.

\section{KESIMPULAN}

Berdasarkan hasil penelitian, maka dapat ditarik kesimpulan sebagai berikut:

1. Terdapat hubungan antara kekuatan otot lengan dengan Overhand pass pada anggota ekstrakurikuler Bola Tangan SMK Negeri 26 Jakarta.

2. Terdapat hubungan antara panjang lengan dengan Overhand pass pada anggota ekstrakurikuler Bola Tangan SMK Negeri 26 Jakarta.

3. Terdapat hubungan antara kekuatan otot lengan dan panjang lengan dengan Overhand pass pada anggota ekstrakurikuler Bola Tangan SMK Negeri 26 Jakarta.

\section{SARAN}

Berdasarkan kesimpulan dan hasil penelitian, maka dapat diajukan saran sebagai berikut:

1. Dalam olahraga permainan seperti cabang Bola Tangan, kemampuan kekuatan fisik sangat perlu untuk diperhatikan. terutama pada kekuatan otot lengan untuk melakukan teknik passing maupun menembak. Diperlukan kualitas otot lengan yang dapat memberikan kekuatan dengan maksimal. Sesuai dengan hal tersebut maka disarankan agar pelatih memperhatikan kontribusi dari kekuatan otot lengan ini dalam memberikan program latihan yang baik.

2. Cabang olahraga bola tangan merupakan cabang olahraga yang masih baru di indonesia,untuk itu hendaknya para peneliti lainnya dapat membuat dan mengembangkan penelitian pada cabang olahraga bola tangan misalnya mengenai minat para angota terhadap kemajuan bola tangan di indonesia,kemampuan fisik dan teknik yang belum diteliti 
serta hal yang berkaitan dengan cabang olahraga bola tangan.

3. Dengan adanya penelitian yang dilakukan oleh peneliti diharapkan agar cabang olahraga bola tangan dapat lebih dikembangkan sedini mungkin, dengan adanya ekstrakurikuler yang ada di sekolah SMK Negeri 26 Jakarta diharapkan agar sekolah lainnya juga dapat melakukan ekstrakurikuler cabang olahraga bola tangan yang diharapkan dapat menciptakan atletatlet berbakat cabang olahraga bola tangan.

\section{DAFTAR PUSTAKA}

Agus Mahendra,Bola Tangan,(Jakarta: Depdikbud,1999),

Aip sjarifudidin,Pendidikan Olahraga,(Jakarta:Cv,Baru 1987)

Clanton Reita E.,Mary Phyl Dwight,(Team Handball: Step to Success.USA 1997)

Dadang Masnun, Kinesiologi, (Jakarta: Fakultas Ilmu Keolahragaan Universitas Negeri Jakarta 2009)

Depdikbud, Kamus Besar Bahasa Indonesia (Jakarta: Balai Pustaka)

Hardianto Wibowo, Anatomi (miologi) (Jakarta : FPOK IKIP Jakarta 1978)

Moeh. Soebroto, Masalah-Masalah dalam kedokteran olahraga, latihan olahraga dan Coaching, (Jakarta:Depdikbud RI,1975)

Pyke Frank S, Toward Better Coaching (canberra : Australia Goverment Publishing Service,1980)

Proyek Pembinaan Dan Pembibitan Olahraga, Tuntunan Mengajar Atletik, (Jakarta : Depdiknas, 1997)

Ronny Kountur, Metode Penelitian untuk Penulisan Skripsi dan Tesis, (Jakarta: PPM, 2007)

Sudjana, Metoda Statistika, (Bandung : Tarsito, 2002)

Surjadji, Tingkat Kesegaran Jasmani Anda ( Jakarta : Departemen Pendidikan Nasional 2000)

Sumadi Suryasubrata, Metodologi Penelitian, (Jakarta : PT Raja Grafindo Persada, 2003)

S. Nasution, Metode Research (Penelitian Ilmiah), (Jakarta: Bumi Aksara, 1998)

Tudor O. Bompa, PERIODIZATION Theory and Methodology of Training, Diterjemahkan oleh tim dosen FIK UNJ, (Jakarta: FIK UNJ Jakarta, 2009) 